\title{
JUVENILE DELINQUENCY IN MALAYSIA: LEGAL FRAMEWORK AND PROSPECTS FOR REFORMS*
}

\author{
Nasimah Hussin**
}

\begin{abstract}
It is undeniable that offences committed by young offenders in Malaysia are increasing. Progress in technology and development in IT has exposed our youngsters to various violent related programmes. The type of offences committed differs from the early days. Thus, it is timely to examine the existing legal framework and to suggest reforms to the system so that the aspects relating to punishment of young offenders can be reviewed. This is necessary to ensure that the punishment is deterrent and rehabilitative whilst at the same time, it would safeguard the interests and welfare of young offenders. This paper examines the application of the law pertaining to the criminal liability of young offenders and their positions in both the civil and shari' ah systems.
\end{abstract}

\footnotetext{
* This article is a revised version of conference paper that has been presented at The $4^{\text {th }}$ World Congress on Family Law and Children's Right at Cape Town South Africa, 20-23 March 2005.

** Assistant Professor, Ahmad Ibrahim Kulliyyah of Laws, International Islamic University Malaysia.
} 


\section{INTRODUCTION}

Juvenile delinquency has been on the rise recently as evidenced by newspaper reports. It dominates discussion at various levels and raises concern among the public, law enforcement officers etc. Since independence, the government of Malaysia has managed to put the country in well-established position economically, socially and politically that any Malaysians can be proud of. However, the rise in the juvenile delinquencies is an issue that must not be neglected, as this will affect future generations that are supposed to lead the country.

Generally juvenile delinquency involves some form of offending acts by youth. The delinquent acts of a juvenile can be divided into two categories; First, acts or omissions which are prohibited and punishable by law under the respective legal systems and second, acts which are known as status offences. ${ }^{1}$ In Malaysia, two forms of status offences are recognizable, ${ }^{2}$ i.e. as follows: (i) being beyond the control of parents, ${ }^{3}$ and (ii) being exposed to moral danger. ${ }^{4}$

In Malaysia, statistics recorded that there were 29,337 juveniles who were arrested for committing offences through the years 2002 until 2006, i.e. the average of 488 cases per month and 16 cases per day. The number of juveniles involved in delinquent acts kept on increasing from time to time. This trend can be alarming. In 2006 alone, the number of arrest stood at 8125 , i.e. the average of 677 cases per month and 22 cases per day. ${ }^{5}$ The detailed figures are shown in the table below.

1 Rule 3.1 of Standard Minimum Rules for the Administration of Juvenile Justice [The Beijing Rules] (UN), 1985 extends the application of its provisions to cover "status offences" prescribed in various national legal systems where the range of behaviour considered to be an offence is wider for juveniles than it is for adults (for example, truancy, school and family disobedience etc).

2 Abdul Hadi Zakaria, Juvenile Delinquency: Its Relationship to the Family and Social Support, in Caring Society Emerging Issues and Future Directions, (ed.) ISIS, Kuala Lumpur, 1990, p. 134.

3 Such as running away from home and being habitually disobedient and incorrigible. See: Section 46 of Child Act 2001 (Act 611).

$4 \quad$ Such as a girl's involvement in prostitution or in employment which facilitates sexual intimacy. See: Section 38 of Child Act 2001 (Act 611).

$5 \quad$ The Royal Malaysian Police, refer: Table 1 and Table 2. 


\section{Table 1:}

Statistics on the involvement of juveniles in criminal cases based on age and gender.

\begin{tabular}{|c|c|c|c|c|c|c|c|}
\hline & & & Ag & & & & \\
\hline Year & No. of cases & 7- 12 & 13-15 & 16-18 & Male & Female & No. of arrest \\
\hline 2002 & 2955 & 113 & 1265 & 2822 & 4066 & 134 & 4200 \\
\hline 2003 & 3647 & 151 & 1593 & 3711 & 5303 & 152 & 5455 \\
\hline 2004 & 3641 & 161 & 1501 & 3899 & 5393 & 168 & 5561 \\
\hline 2005 & 3936 & 161 & 1472 & 4363 & 5849 & 147 & 5996 \\
\hline 2006 & 5007 & 133 & 1661 & 6331 & 7900 & 225 & 8125 \\
\hline Total & 19186 & 719 & 7492 & 21126 & 28511 & 826 & 29337 \\
\hline
\end{tabular}

It can be inferred from table $\mathbf{1}$ above that the tendency to be involved in a delinquent act is found more common in older juvenile compared to younger ones. It can be seen from the statistics that 21,126 out of 29,337 juveniles who were arrested for committing offences are between the ages of 16 - 18 years old. If the above statistics is examined based on gender, it is apparently clear that the involvement of male juvenile in criminal cases is far higher than that of female, i.e. 28,511 out of 29,337 or $97.2 \%$. 


\section{Table 2:}

Statistics on the involvement of juveniles in criminal cases based on type of offences

\begin{tabular}{|c|c|c|c|c|c|c|}
\hline Types of offences & 2002 & 2003 & 2004 & 2005 & 2006 & Total \\
\hline Relating to property & 1845 & 2243 & 2370 & 2663 & 3654 & 12775 \\
\hline Causing hurt & 195 & 179 & 150 & 205 & 403 & 1132 \\
\hline Robbery & 151 & 181 & 170 & 166 & 218 & 886 \\
\hline $\begin{array}{l}\begin{array}{l}\text { Possessing weapon } \\
\text { ammunition }\end{array} \\
\end{array}$ & 145 & 158 & 147 & 164 & 214 & 828 \\
\hline Rape & 111 & 122 & 128 & 104 & 203 & 668 \\
\hline $\begin{array}{l}\text { Using criminal force or } \\
\text { assault }\end{array}$ & 49 & 51 & 61 & 64 & 98 & 323 \\
\hline Affecting life & 32 & 38 & 31 & 28 & 22 & 151 \\
\hline Extortion & 31 & 20 & 33 & 27 & 36 & 147 \\
\hline $\begin{array}{lll}\text { Under Dangerous Drug } \\
\text { Act }\end{array}$ & 0 & 56 & 0 & 0 & 0 & 56 \\
\hline Other offences ${ }^{6}$ & 396 & 599 & 551 & 515 & 159 & 2220 \\
\hline Total & 2955 & 3647 & 3641 & 3936 & 5007 & 19186 \\
\hline
\end{tabular}

From the above statistics, it is revealed that offences committed by juveniles, which rank highest are offences relating to property, i.e. 12,775 cases or $66.6 \%$. These include theft, house breaking, theft of motor vehicle, snatch theft, etc. Offences relating to property are prevalent. The second highest are offences affecting human body such as causing injury, involving in a fight, i.e. 1132 cases or 5.9\%, followed

$6 \quad$ Other offences include receiving stolen property, cheating and dishonestly inducing delivery of property, mischief, criminal intimidation, furnishing false information, sale, etc., of obscene books, etc. 
by robbery which also includes gang robbery, i.e. $4.6 \%$ then possessing weapon or ammunition, i.e. $4.3 \%$, the offence of rape, i.e. $3.5 \%$ and followed by the rest of the offences.

The statistics disclosed above are more than enough to describe the seriousness of juvenile delinquency problems in Malaysia. The question arises as to what extent the existing laws manage to curb this problem? What is the best approach to deal with these young offenders and what is the most suitable punishment to be inflicted to deter the juveniles from the commission of delinquent acts.

This paper will discuss this scenario in the Malaysian context. It will explain the legal provisions pertaining to the criminal liability of child offenders and their positions. A reference will be made to the position of child offenders in Islamic law as it is applied in Syariah Courts of Malaysia. ${ }^{7}$

\section{BASIS OF CRIMINAL ACCOUNTABILITY}

A person who intentionally commits an unlawful act must bear the consequence of his act. He must be punished when the crime is established and he is considered having the criminal accountability. The criminal accountability rests on three bases. First, the act committed is unlawful. Second, the unlawful act is committed with free will. Third, the

$7 \quad$ The Federal Constitution of Malaysia provides that, other than in the Federal Territories, the constitution, organization and procedure of the Syariah Courts are state matters over which the state has exclusive legislative and executive authority. The Syariah Courts were established under the state laws (i.e. enactments). The state enactments also provide for both the civil and criminal jurisdiction of the Syariah Courts. For criminal jurisdiction, the enactments list a number of offences that can be tried in the Syariah Courts. Generally, the offences can be divided into six categories, namely, matrimonial offences, offences relating to decency, offences relating to the consumption of intoxicants, offences concerning the spiritual aspect of Muslim communal life, offences relating to conversion of religion and miscellaneous offences apart from those categories mentioned. The jurisdiction of Syariah Courts is applied only to persons professing the religion of Islam. For further details, see: Halsbury's Laws of Malaysia, vol. 14, MLJ, Kuala Lumpur, 2002, p. 497. 
unlawful act is committed by an adult and sane person who can distinguish between right and wrong. In the absence of these bases, a person committing the offence will not be held liable and thus the punishment cannot be imposed.

If a person commits the offence with intention, the first thing that is to be determined is whether he has the mental capacity to understand the nature and consequence of his act before any punishment can be imposed on him. The degree of understanding varies according to a person's age.

The following discussion will deal with the stages of a person's age to determine those who can be categorized as juveniles and their liabilities according to Malaysian law and Islamic law.

\section{DEFINITION OF A CHILD / JUVENILE}

The (UN) Convention on the Rights of the Child 1989 defines children as,

"All human beings under the age of 18 , unless the relevant national laws recognize an earlier age of majority.” (Article 1)

According to the Rule 2.2 (a) of the Standard Minimum Rules for the Administration of Juvenile Justice [The Beijing Rules] (UN), 1985,

"A juvenile is a child or young person who, under, the respective legal systems, may be dealt with for an offence in a manner which is different from an adult." 8

In Malaysia, there are a number of statutes, which have the provisions on this issue. They are however, vary slightly from one statute

$8 \quad$ It is stated in the commentary to the rule, that it should be noted that the age limits will depend on, and are explicitly made dependent on each respective legal system, thus fully respecting the economic, social, political, cultural and legal system of Member States. This makes for a wide variety of ages coming the definition of "juvenile," ranging from 7 years to 18 years or above. 
to the other as each of the statutes is meant for specific needs and purposes. The most relevant provision defining the word "child" is section 2 of the Malaysian Child Act 2001 (Act 611), ${ }^{9}$ which states that a "child" is:

(a) a person under the age of eighteen years; and

(b) in relation to criminal proceedings, means a person who has attained the age of criminal responsibility as prescribed in section 82 of the Penal Code [Act 574].

There are also provisions pertaining to this matter in Evidence Act 1950 and Age of Majority Act 1971 (Act 21). ${ }^{10}$

From the above provision, it can be said that anybody who is below eighteen years old will be treated differently from an adult, particularly in respect of procedure and punishment. In terms of the civil liability, generally those who are below eighteen years old will not be held liable. Nevertheless, in relation to criminal proceedings, as mentioned in the Child Act 2001, the age of criminal responsibility of a child is prescribed in section 82 of the Penal Code (Act 574). ${ }^{11}$

\section{WHEN DOES THE CRIMINAL LIABILITY OF A CHILD COMMENCE?}

In relation to this issue, section 82 and 83 of the Malaysian Penal Code (Act 574) must be studied. Section 113 of the Evidence Act 1950 is also relevant with this issue.

$9 \quad$ Provisions in the Child Act 2001 are combination of three Acts which have been repealed, i.e. the Women and Girls Protection Act 1973 (Act 106), the Child Protection Act 1991 (Act 468) and the Juvenile Courts Act 1947 (Act 90).

10 Section 2 of the Age of Majority Act 1971 provides that a minor is any female or male whose age is under eighteen. See also: Section 90 of the Penal Code, Section 10 of the Contract Act 1950, Section 10 of the Marriage and Divorce Act 1976.

11 The Child Act 2001 uses the word "child" in its provisions which also covers "juvenile." Thus the words child and juvenile are used interchangeably in this paper. 
Section 82 of the Code provides:

Nothing is an offence, which is done by a child under ten years of age.

The above section gives an absolute protection to the child below ten from being prosecuted and punished for his offence. The presumption that the child below ten is incapable of committing a crime is irrebuttable. It means that no action will be taken against the child of this age who has committed a crime even if the crime is of a serious one. ${ }^{12}$

The presumption that the child below ten is incapable of committing a crime is based on the presumption that the child is incapable of understanding the nature and consequence of his act. This principle is adopted from the doctrine of doli incapax as applied in English law with the exception of the differences of the age limit. ${ }^{13}$ In all circumstances, the child is required to produce his birth certificate or any other document that is acceptable by the court to prove that he is less than ten years old. Unlike section 82 that gives full protection for a child below ten who commits an offence, as he is doli incapax, section 83 of the Penal Code, however, provides conditional protection for a child above ten and below twelve years old. It provides:

Nothing is an offence which is done by a child above ten years of age and under twelve, who has not attained sufficient maturity of understanding to judge of the nature and consequence of his conduct on that occasion.

A child of this age is also presumed to be doli incapax (incapable of committing crime) but the presumption is rebuttable depending upon his degree of understanding the nature and consequence of his act at the

12 See: $R v$ Ba Ba Sein (1938) Rang. 400, see also: Walters $v$ Lunt (1951) 2 All E.R 645.

13 In the case of Elliot $v C$ (1983) All E.R 1005, the court observed that, the presumption of 'doli incapax' is derived from a recognition of the immaturity of children who do not posses a fully developed understanding of what is right and wrong nor has the ability to fully appreciate the consequences of his acts. See: Allen, Michael J, Textbook On Criminal Law, Blackstone Press Ltd, London, 1991, p. 95. 
time of the commission of the crime. If it is proved that the child does not understand the nature and consequence of the crime that he has committed, he will not be held liable. ${ }^{14}$ It is to be noted that the burden of proof to determine whether or not the child offender has attained sufficient understanding as to the nature and consequence of the crime is on the part of the child. In English law, on the other hand, the burden to prove this presumption is on the prosecutor to show mischievous discretion of the child. Normally the court will take into account the child's action, character or expression immediately prior to and after the commission of a crime. The knowledge of the child as to the nature and consequence of the act committed by him is a clear proof that the child has attained sufficient maturity and understanding as to the wrongfulness of his act. As such, the children are considered as equal to the adults and therefore, their standard of responsibility is also similar. However, the benefit of the doubt will always be given to the child. ${ }^{15}$

It can be implied from the above, that a child whose age is 12 years old but below eighteen years old may be held liable criminally. The procedure and punishment are, however, different to those applicable to the adults.

It must be remembered that there is one more provision in the Evidence Act 1950 that protects the child offender pertaining to the crime of rape. Section 113 of the Act provides that:

It shall be an irrebuttable presumption of law that a boy under the age of thirteen years is incapable of committing rape.

It can be said that section 113 of the Act provides absolute protection to a male child below the age of thirteen in respect of the crime of rape. Thus a boy below the age of thirteen will not be prosecuted for committing rape as it is legally presumed that he is incapable of having sexual intercourse. Nevertheless, the boy can be charged for attempted rape instead. ${ }^{16}$

See Ulla Mahapatra [1950] A.I.R. (Cut.) 293.

Molly Cheang, Criminal Law of Malaysia and Singapore: Principles of Liability, Professional (Law) Books Publishers, Kuala Lumpur, 1990, p. 86.

See: Nga Tun Kaing [1917] 18 Cr. L.J. 943. 
The next discussion will deal with the issue of determining who can be categorised as a child according to Islamic law as applied in the Syariah Courts of Malaysia. Section 51 of the Syariah Criminal Offences (Federal Territories) Act 1997 (Act 559) provides:

Nothing is an offence which is done by a child who is not bāligh.

The word "bäligh" is interpreted in section 2(1) of the same Act as to mean having attained the age of puberty according to Islamic law. This provision is not clear in determining who can be categorized as a child who is exempted from criminal liability in the Syariah Court, as there is no specific age limit. However, there is one more provision pertaining to the sentencing and the procedure to be followed in sentencing the youthful offender in the Shariah Criminal Procedure (Federal Territories) Act 1997 (Act 560). "Youthful offender" is interpreted in section 2(1) of the Act as to mean an offender above the age of ten and below the age of sixteen years. ${ }^{17}$ Apart from those provisions, Islamic Family Law (Federal Territories) Act 1984 (Act 303) also has relevant provision on the issue of the determination on the age of a child. ${ }^{18}$

It is necessary to discuss further the issue on the age of puberty and criminal responsibility according to Islamic Law.

In Islamic law, the age of the offender is relevant when considering punishment to be inflicted on the child. Criminal responsibility in Islamic law is based on understanding (idrāk) and free-will (ikhtiyār) and its degree varies according to a person's age. There are three stages, which any ordinary person will experience from the very beginning of his life until he reaches the age of puberty, namely:

1. Absence of understanding, when a child is unable to distinguish between right and wrong or between good or bad. A child at

17

18

See: Syariah Court Prosecutor of Perak v Jaffary and Hasliza (1991) $8 \mathrm{JH} 99$.

Section 88 (4) of the Islamic Family Law (Federal Territories) Act 1984 (Act 303) provides that: A person shall, for the purposes of guardianship of person and property, be deemed to be a minor unless he or she has completed the age of eighteen years. See also: Section 79 of the Islamic Family Law (Federal Territories) Act 1984. 
this stage is known as a sabiy ghayr mumayyiz. This stage begins from the day a child is born until he reaches seven years old. In fact, there is no specific age that a child is regarded as capable of distinguishing something since some children might do so earlier than others. However, the jurists limit it to the age of seven based on average occurrence, in order to standardise the judgement and to facilitate the judge in making any decision in relation to this matter. A child offender of this age is given absolute protection by the Islamic law. It seems similar with the doctrine of doli incapax. If a child at this stage commits any crime, he will not be accountable for any punishment, either hadd ${ }^{19}$ or qișa $\underline{s}^{20}$ or $\operatorname{ta}^{2} \mathrm{z} \overline{\mathrm{r}},{ }^{21}$ so long as he has not reached the age of seven. ${ }^{22}$ This is based on a hadith of the Prophet which means:

"Three persons are excused from responsibilities; a child until he attains the age of puberty; a sleeping

Hadd (plural: $h u d \bar{u} d$ ), is a crime punishable with a fixed punishment imposed as the right of public, or known as the right of God. Hudüd crimes and their punishments are mentioned clearly in the text of the Qur'ān and the Sunnah. The crimes of hudūd in Islamic criminal law are zinā (adultery or fornication), qazf (false accusation of zinā), theft, robbery, drinking intoxicants, apostasy and rebellion. When a crime of hadd is established, the prescribed punishment must be imposed. It cannot be reduced nor pardoned.

Qisạs is a crime punishable with a fixed punishment imposed as the right of individual. Qișās crimes and their punishments are mentioned clearly in the text of the Qur'ān and the Sunnah. The crimes include homicide and causing bodily harm to others. Since these crimes involve the right of an individual, the victim has the right to choose, whether to demand the infliction of punishment on the offender or to pardon him.

$21 \quad T a^{\prime} z \bar{r} r$ is a crime punishable with penalties that are discretionary, i.e. it is left to the discretion of the judge to determine the suitable punishment to be imposed on the offender. It consists of all kinds of transgression where no specific and fixed punishment is prescribed.

'Awdah, 'Abd al-Qādir, Al-Tashrī‘ al-Jinā'ī al-Islāmī, vol.1, 13th ed., Mu’assasah al-Risālah, Beirut, 1994, p. 601, Bahnasi, Ahmad Fathī, AlMas'uliyyah al-Jinā'iyyah fī al-Fiqh al-Islāmī, 3rd ed., Cairo, Dār alShurūq, 1984, p. 270. 
man until he is awake; and an insane until he becomes sane." 23

2. Infirm understanding, when a child is already able to distinguish between right and wrong or between good or bad, but not in a full way. A child, at this stage, is known as a sabiy mumayyiz. This stage begins from the age of seven until the child reaches the age of puberty, i.e fifteen years old as fixed by the Shāfi'îs, the Hanbalīs and some of the Mālikīs. Whenever a child reaches the age of fifteen he is considered as having reached puberty legally even though he might not have done so physically. Abū Hanifah, however, fixes the age of puberty at eighteen, and in another report, he fixes it at nineteen years old for a boy and seventeen years old for a girl. The dominant opinion of the Mālikī School agrees with the opinion of Abū Hanīfah, which fixes it at eighteen, while some others fix it at nineteen. ${ }^{24}$

If a child of this age commits a crime, the criminal liability has already begun; nevertheless it is not similar with that of the adult particularly if the offence committed is of hadd or qișas type. The child will not be accountable for a crime of hadd or qișạs but he should be disciplined with a ta 'zir punishment. This means that he may be punished again whenever he repeats a crime but he will not be considered a criminal. The types of ta 'zir punishments that can be inflicted on a sabiy mumayyiz are no more than reprimand or beating. ${ }^{25}$ This is due to the fact that his degree of understanding as to the nature and consequence of his act is still weak. The determination of this age is based on the hadith of the prophet, which means:
"Teach your children to perform prayer when they reach the age of seven and beat them (for failure to perform prayer) by the age of ten.”26

\footnotetext{
23 Abū Dawūd, Sulaymān bin al-Ash'ath al-Sajastānī, Sunan Abī Dawūd, Dār Ibn Hazm, Beirut, 1998, ḥadìth No. 4402.

24 'Awdah, al-Tashrī al-Jinā'’̄ al-Islāmī, vol. i, p. 601, Bahnasī, AlMas'ūliyyah al-Jinā'iyyah fī al-Fiqh al-Islāmī, p. 271.

25 'Awdah, p. 602, Bahnasī, p. 275.

26 Abū Dawūd, Sunan, Hadīth No. 495, p. 84.
} 
3. Full power of understanding, i.e. when a person can distinguish everything in as complete way as possible. At this stage, he is known as bāligh wa rāshid (a mature person). This stage begins when a person reaches fifteen years old, according to the majority of the jurists, or eighteen years old according to Abū Hanīfah and the dominant view of the Mālikis. A person at this age is fully responsible for any crime that he has committed, whether it is of a hadd or qișās or ta ${ }^{\mathrm{z}} \overline{\mathrm{i}} \mathrm{r} .{ }^{27}$

From the above discussion, it can be concluded that criminal responsibility of a child in Islamic law begins at seven years old. A child who commits a crime cannot be called a criminal even though he has been punished more than once. This means that if he commits the offence again after the age of puberty, he is considered as a first offender. The punishment imposed also should be moderate.

\section{THE EXTENT OF THE CRIMINAL RESPONSIBILITY OF A CHILD}

After discussing and analyzing the concept of child delinquency and his criminal responsibility in the Malaysian context as well as those of Islamic law, we turn our discussion to see the extent of which the child is criminally liable. If he is held liable on criminal ground, then what sort of punishment to be inflicted on a child offender.

In Malaysia, the extent of criminal liability of a child offender is different from that of an adult offender particularly in respect of procedure and sentencing. It is specifically provided for in the Child Act 2001. A child who is alleged to have committed an offence shall not be arrested, detained or tried except in accordance with the Act. ${ }^{28}$ When a child is charged with an offence, he must be tried in a special court, known as the Court for Children ${ }^{29}$ whereby the building or room or days for sitting

\footnotetext{
27 'Awdah, al-Tashrī' al-Jinā'̀̄ al-Islämī, vol. i, p. 601.

28 Section 83(1).

$29 \quad$ Except when children are jointly tried with adults then proceedings will be carried out in the adult court. See: section 83(4). Or if the offences committed are those punishable with death then it will be tried in the High Court.
} 
is different with that of the adult courts. ${ }^{30}$ The name, address or educational institution or any particulars calculated to lead to the identification of any child so concerned shall not be revealed, recorded nor published in any newspaper or magazine or transmitted through any electronic medium. ${ }^{31}$

It is to be noted that the words "conviction" and "sentence" should not be used in relation to a child dealt with by the Court for Children and any reference in any written law to a person convicted, a conviction and a sentence shall, in the case of a child, be construed as a child found guilty, a finding of guilt and an order made upon a finding of guilt respectively. ${ }^{32}$

Pertaining to the punishment to be imposed on a child offender, section 91(1) Child Act 2001 provides that Court for Children has the jurisdiction to impose a punishment on a child whose offence has been proved in the Court, i.e. as the following:

(a) Admonish and discharge the child.

(b) Discharge the child upon his executing a bond to be of good behaviour and to comply with such conditions as may be imposed by the Court.

(c) Order the child to be placed in the care of a relative or other fit and proper person for such period and conditions as determined by the Court.

(d) Order the child to pay a fine, compensation or costs.

(e) Make a probation order under section 98.

(f) Order the child to be sent to an approved school (for a child above ten years old) or a Henry Gurney School (for a child above fourteen years old).

(g) Order the child, if a male, to be whipped with not more than ten strokes of a light cane within the Court premises.

(h) Impose on the child, if he is aged fourteen years and above and the offence is punishable with imprisonment and subject to subsection 96 (2), any term of imprisonment which could be awarded by a Session Court.

\footnotetext{
Section 83(2). See also: section 11 and 12.

$31 \quad$ Section 15.

32 Section $91(2)$.
} 
Imprisonment is the last choice of punishment to be imposed on a child. If other type of punishment such as fining or probation or being sent to a place of detention or an approved school or a rehabilitation school or else is more suitable with the conditions and welfare of the child, then imprisonment will not be resorted to. ${ }^{33}$ If a child offender is sent to prison, he must be separated from adult prisoners. ${ }^{34}$

It is to be noted that death sentence cannot be inflicted on a child offender even if he is found guilty of committing an offence punishable with death. ${ }^{35}$ The court would instead order him to be detained in a prison during the pleasure of the ruler (King). The person's case shall be reviewed at least once a year and may be recommended for the early release or further detention. ${ }^{36}$

Coming back to the provision pertaining to the procedure in sentencing the youthful offenders in the Syariah Court, section 128 of the Syariah Criminal Procedure (Federal Territories) Act 1997 (Act 560) provides that:

\begin{abstract}
When any youthful offender is convicted before any Court of any offence punishable by fine or imprisonment, such Court shall instead of awarding any term of imprisonment in default of payment of the fine or passing a sentence of imprisonment-
\end{abstract}

For best interests of child offenders, the Social Welfare Department Malaysia has established a number of rehabilitation institutions with the objective to reform, guide, educate and protect them. Up to the present, there are 28 rehabilitation institutions including 8, which are meant for girls only. These institutions can accommodate up to 2760 child offenders.

This provision does not appear to be applicable in cases tried under Essential (Security Cases) Regulation (ESCAR) 1975.Regulation 3 provides: Where a person is accused or charged with security offence, he shall, regardless of his age, be dealt with and tried in accordance with the provisions of these Regulations and the Orders make thereunder, and the Juvenile Courts Act 1947 shall not apply to such person. See: Lim Hang Seoh v. Public Prosecutor [1978] 1 MLJ 68. Section 97. 
(a) order such offender to be discharged after due admonition if the Court shall think fit; or

(b) order such offender to be delivered to his parent or to his guardian or nearest adult relative or to such other person, as the Court shall designate, on such parent, guardian, relative or other person executing a bond with a surety, as the Court may require, that he will be responsible for the good behaviour of the offender for any period not exceeding twelve months or without requiring any person to enter into any bond, make an order in respect of such offender ordering him to be of good behaviour for any period not exceeding two years and containing any directions to such offender in the nature of the condition referred to in paragraphs 130(a),(b) and (c)which the Court shall think fit to give.

(2) The Court before which a youthful offender is convicted may, in addition to or instead of punishing such offender in the manner provided in this section, inflict on his parent or guardian a fine not exceeding two hundred ringgit in any case in which such Court, after summary inquiry, is satisfied that such parent or guardian has, by neglecting to take proper care or otherwise, conduced to the misconduct of such offender:

Provided that no parent or guardian shall be fined without his having had an opportunity of being heard and, if he desires it, of adducing evidence in his defense. 


\section{CONCLUSION}

From the above discussion, it can be concluded that the age of a child is relevant when considering the liability, procedure and punishment to be imposed. It is decided that the age of criminal responsibility as provided for in the Malaysian law begins at the age of ten years. It is, however, depending upon his level of understanding as to the nature and consequence of his act at the time of the commission of the crime. When a child has attained the age of twelve but below the age of eighteen the criminal liability is apparently clear with the exception to the crime of rape whereby in that case the liability of a child begins at thirteen.

Whilst in the Syariah Court, the criminal responsibility of a person is determined upon attaining the age of puberty according to Islamic Law. The discussion of the Muslim jurists maintains that the criminal responsibility of a child begins at the age of seven years and continues to be treated as a child until he attains puberty. On the issue of determining the age of puberty, there are two main views; one is 15 years old and the other is 18 years old. Meanwhile, the Syariah Criminal Procedure (Federal Territories) Act 1984 interprets “youthful offender" as an offender above the age of ten and below the age of sixteen years. Thus a study should be carried out to consider this discrepancy to prevent different standards imposed on children upon entering the criminal justice system.

The Court, in determining the type of punishment to be inflicted on child offenders, should take into its account the welfare of the children so that it would achieve the objective to serve as deterrent and rehabilitative. The procedure to be followed in sentencing child offenders should cater for child-friendly atmosphere so that it would not affect their good names nor damage their reputation in the society.

For best interests of child offenders, a provision must be expressly inserted to exclude children from capital punishment or life imprisonment in the Child Act 2001 and to take out these types of punishments from all related statutes that regulate child offences. Imprisonment should not be imposed unless the child is guilty of a serious act involving violence against another person or of repeated commission of serious offences, unless there is no other appropriate punitive measure. Consideration should be given to cater for the different and special needs of child prisoners. Providing national curriculum based education in any of its form for child prisoners should not be paid less attention, as it plays a very important 
role in strengthening and reforming their minds and souls as well as securing their future livelihood.

It must be remembered that the justice system should always emphasize the well being of the child and ensure that any punishment of child offenders is always in proportion to the circumstances of both the offenders and the offence. Punitive sanction is not the only approach to resolve the issue of child delinquencies. The role of every individual in the society either in the form of organisations or societies is necessary to ensure that the children are properly guided to face the challenging world today. 